\title{
Variasi Biokimia Genetik Populasi Ikan Betutu (Oxyeleotris marmorata, BLKr.) di Waduk Penjalin Brebes
}

\author{
Biochemical Genetic Variation of Sand Goby (Oxyeleotris marmorata, BLKr.) Population \\ in Penjalin Water Reservoir Brebes
}

\author{
Agus Hery Susanto* dan Suhestri Suryaningsih
}

Fakultas Biologi Universitas Jenderal Soedirman, Kampus Karangwangkal Purwokerto

Telp.(0281)638794 Fax.(0281)631700 E-mail: susanto1408@yahoo.co.id *Penulis untuk korespondensi

\begin{abstract}
Penjalin water reservoir in Brebes Regency, Central Java, is one of the habitats of the sand goby. A study on its genetic diversity using approaches of isozyme analysis was needed to support domestication of the fish in this area. This study was aimed at the biochemical-genetic variation of sand goby population in Penjalin water reservoir based on esterase (EST), peroxidase (PER), malate dehydrogenase (MDH), aspartate amino-transferase (AAT), and acid phosphatase (ACP) polymorphisms. Visualization of the isozymes was carried out employing horizontal electrophoretic technique with potato starch gel and buffer system of L-histidin monohydrate. Of the five isozymes, ACP was not well-visualized in all samples tested while the remaining four showed no polymorphisms. It could be concluded that there is no biochemical-genetic variation of sand goby population in Penjalin water reservoir based on isozymes of EST, PER, MDH, and AAT.
\end{abstract}

Key words: sand goby, isozyme, biochemical-genetic variation, horizontal electrophoresis

Diterima: 28 Oktober 2005, disetujui: 03 Juli 2006

\section{Pendahuluan}

Ikan betutu (Oxyeleotris marmorata, BLKr.) merupakan salah satu jenis ikan liar air tawar dari familia Gobiidae yang mempunyai potensi cukup besar sebagai komoditas ekspor ke berbagai negara. Namun, hingga kini ketersediaannya belum dapat memenuhi peluang tersebut karena sepenuhnya masih bergantung kepada hasil penangkapan di alam (Nyuwan, 2000). Waduk Penjalin di Kabupaten Brebes, Jawa Tengah, dengan luas areal sekitar 125 ha merupakan salah satu habitat ikan betutu. Dalam keseharian masyarakat di sekitarnya melakukan penangkapan ikan betutu secara liar (Anonim, 1989). Guna menanggulangi berlanjutnya praktek penangkapan liar tersebut perlu dilakukan upaya domestikasi. Menurut Gaffar dan
Nasution (1990) ikan betutu termasuk salah satu spesies ikan liar yang berpotensi untuk didomestikasi. Dalam menunjang upaya domestikasi ikan betutu diperlukan kajian biologi, yang antara lain meliputi aspek genetika populasi.

Studi genetika pada suatu populasi spesies organisme dimaksudkan untuk memberikan evaluasi mengenai variasi genetik populasi tersebut. Menurut Suryadi (2002) studi tentang variasi genetik merupakan aspek yang sangat penting dalam pelestarian dan juga pemanfaatan plasma nutfah. Indriani et al., (2002) menyatakan bahwa semakin tinggi variasi genetik plasma nutfah, semakin besar peluang untuk memperoleh organisme dengan sifat yang diinginkan.

Salah satu pendekatan yang dapat ditempuh dalam melakukan estimasi tingkat 
variasi genetik pada populasi alami adalah aplikasi teknik biokimia berupa analisis isozim sehingga pendekatan ini sering disebut sebagai studi variasi biokimia genetik. Menurut Adams dalam Mansyah, et al., (1999) studi variasi genetik atas dasar polimorfisme sejumlah lokus isozim dapat dengan cepat memberikan gambaran variasi genetik populasi yang dipelajari. Keuntungan lainnya dalam penggunaan isozim adalah bahwa alel yang berbeda akan diwariskan secara kodominan sehingga individu homozigot dapat dibedakan dengan individu heterozigot berdasarkan atas penampilan pola pita yang dihasilkan. Selain itu, secara teknis peralatan dan bahan yang diperlukan relatif tidak terlalu mahal dan percobaan dapat dilakukan dengan mudah di laboratorium (Brar dalam Hadiati et al., 2002).

Beberapa isozim yang lazim digunakan dalam studi variasi genetik, khususnya pada ikan, antara lain esterase (EST), peroksidase (PER), malat dehidrogenase (MDH). aspartat amino transferase (AAT), dan acid phosphatase (ACP) (Permana et al., 2001). Pada ikan sidat isozim EST, PER, dan AAT dilaporkan dapat divisualisasikan dengan baik, sementara MDH tidak memunculkan pita yang jelas (Susanto et al., 2004a). Sebaliknya, pada ikan bandeng EST dan PER tidak tervisualisasikan, sedangkan $\mathrm{MDH}$, AAT, dan ACP menghasikan pola pita yang jelas (Susanto et al., 2004b).

Penelitian ini bertujuan untuk mengetahui variasi biokimia genetik populasi ikan betutu di Waduk Penjalin Kabupaten Brebes berdasarkan atas polimorfisme isozim esterase, peroksidase, malat dehidrogenase, aspartat amino transferase dan acid phosphatase. Hasil penelitian ini diharapkan dapat digunakan sebagai landasan dalam evaluasi potensi genetik plasma nutfah ikan betutu yang diperlukan bagi penentuan strategi konservasi dan juga upaya domestikasinya.

\section{Metode Penelitian}

Bahan penelitian berupa 11 ekor ikan betutu Waduk Penjalin Brebes dengan kisaran panjang tubuh antara 15 dan $20 \mathrm{~cm}$.
Elektroforesis dilakukan menggunakan gel pai kentang (Sigma S-5116).

Bufer gel dibuat dengan melarutka 1,048 g L-histidin monohidrat 5mM ke dalan akuades hingga mencapai volume $1000 \mathrm{ml}$ Larutan ini dihomogenkan dengan magneti stirrer dan diatur pHnya agar menjadi 6 denga cara menambahkan tris atau $\mathrm{NaOH}$ secukupnya. Untuk pembuatan gel pati, 100 pati kentang dilarutkan ke dalam $330 \mathrm{ml}$ bufe gel. Sementara itu, $670 \mathrm{ml}$ bufer gel lainny dididihkan dalam microwave. Setela mendidih, bufer gel dicampur dengan laruta pati dan dididihkan kembali sampai terliha jernih, kemudian bufer gel disambungka dengan selang desikator sampai gelembun udara dalam larutan pati terangkat. Larutan pat yang telah homogen tersebut dituangkan $\mathrm{k}$ dalam cetakan elektroforesis yang telah dioles parafin dan diberi selotip. Setelah dingin, ge yang terbentuk dari larutan pati ditutup denga plastik yang telah diolesi parafin cair da disimpan pada suhu $5^{\circ} \mathrm{C}$.

Pembuatan bufer ekstraksi dilakuka dengan melarutkan 70,45 mg L-asam askorba $10 \mathrm{mM}, 193,9 \mathrm{mg}$ L-sistein $40 \mathrm{mM}, 0,12 \mathrm{~m}$ triton X-100, dan $250 \mathrm{mg}$ PVP-40 ke dalan akuades hingga diperoleh volume $40 \mathrm{ml}$ Larutan ini dihomogenkan dengan magneti stirrer dan diatur pHnya agar menjadi 8 dengan penambahan $0,1 \mathrm{M} \mathrm{Na} \mathrm{NPO}_{4} \cdot 2 \mathrm{H}_{2} \mathrm{C}$ atau $\mathrm{HCl}$.

Sementara itu, bufer elektroda dibua dengan melarutkan $10,55 \mathrm{~g}$ asam sitra monohidrat $50 \mathrm{mM}$ dan $18,16 \mathrm{~g}$ tri hidroksimetil aminometan $150 \mathrm{mM}$ ke dalan akuades hingga diperoleh volume $1.000 \mathrm{ml}$ Larutan ini dihomogenkan dengan magneti stirrer dan diatur $\mathrm{pH}$ nya agar menjadi $\theta$ dengan penambahan $\mathrm{HCl}$ atau $\mathrm{NaOH}$.

Setelah gel pati dan semua bufer yan, diperlukan selesai dibuat, dilakukan ekstraks isozim dari jaringan otot ikan betutu. Jaringa otot diambil dari bagian dorsal tubuh ika betutu segera setelah ikan tersebut dimatikan Jaringan ini diambil menggunakan skalpe kemudian dimasukkan ke dalam mortar yan telah diberi pasir kuarsa dan bufer ekstraks sebanyak 0,5 ml. Selanjutnya, jaringan digeru sampai halus. Setelah jaringan halus da homogen, dimasukkan kertas saring seukura 
lebar sumuran gel elektroforesis untuk menyerap cairan ekstrak jaringan otot sampel yang diperoleh.

Elektroforesis dilakukan pada tegangan 100 Volt selama 30 menit sebagai fase awal dan dilanjutkan pada tegangan 150 Volt selama 3 jam. Jarak migrasi enzim dikontrol dengan memasukkan bromophenol blue pada sumuran paling tepi (yang tidak berisi sampel). Setelah elektroforesis selesai, gel diambil dari bejana elektroforesis dan dibelah ke arah horizontal hingga menjadi lima lembaran gel, sesuai dengan jumlah pewarna isozim yang telah disiapkan. Tiap lembaran gel direndam dalam masing-masing larutan pewarna selama 24 jam.

Pewarna esterase terdiri atas $0,05 \mathrm{~g} 1$ naftil asetat; 0,05 g 2-naftil asetat; $5 \mathrm{ml}$ aseton; dan $0,1 \mathrm{~g}$ fast blue RR salt; dengan pelarut dan pengatur $\mathrm{pH}$ berupa $100 \mathrm{mM}$ sodium fosfat $\mathrm{pH}$ 7 hingga mencapai volume $100 \mathrm{ml}$. Pewarna peroksidase terdiri atas $0,05 \mathrm{~g} \mathrm{CaCl}_{2} ; 0,5 \mathrm{ml}$ $\mathrm{H}_{2} \mathrm{O}_{2} 3 \%$; 0,05 g 3-amino 9-etil karbasol; $5 \mathrm{ml}$ aseton/N-dimetilformamid; dengan pelarut dan pengatur $\mathrm{pH}$ berupa $50 \mathrm{mM}$ natrium asetat $\mathrm{pH}$ 5 hingga mencapai volume $100 \mathrm{ml}$. Pewarna malat dehidrogenase terdiri atas $0,01 \mathrm{~g}$ NAD; 0,15 g asam malat; 0,01 g NBT; 0,002 g PMS; dengan pelarut dan pengatur $\mathrm{pH}$ berupa $50 \mathrm{mM}$ tris $\mathrm{HCl} \mathrm{pH} 8,5$ hingga mencapai volume 50 $\mathrm{ml}$. Pewarna aspartat amino transferase terdiri atas 0,0292 $\mathrm{g} \alpha$-asam keto glutarat; $1,07 \mathrm{~g} \mathrm{~L}$ asam aspartat; 4 g PVP-40; 0,4 g EDTA $\mathrm{Na}_{2}$ salt; 11,36 g Na $2 \mathrm{HPO}_{4} \cdot \mathrm{H}_{2} \mathrm{O}$; dengan pelarut akuades hingga mencapai volume $800 \mathrm{ml}$. Pewarna acid phosphatase terdiri atas $50 \mathrm{ml}$ Na-1-naftil; $50 \mathrm{~g} \mathrm{MgCl}_{2} ; 50 \mathrm{~g}$ fast garmet $G B C$ salt; $50 \mathrm{ml}$ aseton; dengan pelarut dan pengatur $\mathrm{pH}$ berupa $50 \mathrm{mM}$ natrium asetat $\mathrm{pH} 5$ hingga mencapai volume $200 \mathrm{ml}$.
Gel yang telah diwarnai dan memperlihatkan pola migrasi pita enzim, dicuci dengan air mengalir dan segera difoto untuk dianalisis hasil visualisasinya. Data yang diperoleh dari hasil elektroforesis ditransfer ke dalam zimogram untuk selanjutnya dilakukan perhitungan frekuensi alel dan heterozigositas menurut Suryani et al., (2001) sebagai berikut.

$$
p=P+1 / 2 H
$$

$\mathrm{p}=$ frekuensi alel

$\mathrm{P}=$ fekuensi salah satu genotipe homozigot

$\mathrm{H}=$ frekuensi genotipe heterozigot

Jika nilai $\mathrm{p} \geq 0,95$, maka lokus yang bersangkutan dikatakan bersifat monomorfik, sedangkan jika nilai $\mathrm{p}<0,95$, maka lokus yang bersangkutan dikatakan polimorfik. Sementara itu, heterozigositas dihitung atas dasar frekuensi alel pada setiap lokus dengan rumus:

$$
H e=1-\sum X i^{2}
$$

$\mathrm{He}=$ heterozigositas

$X i=$ frekuensi alel ke-i

Data hasil perhitungan frekuensi alel dan heterozigositas dianalisis secara deskriptif untuk memberikan gambaran mengenai variasi biokimia genetik populasi ikan betutu di Waduk Penjalin.

\section{Hasil dan Pembahasan}

Dari kelima isozim yang dicoba, ACP tidak dapat divisualisasikan dengan baik pada semua sampel yang diuji. Sementara itu, PER hanya tervisualisasi pada sampel nomor 7,8 , 10, dan 11, sedangkan AAT hanya muncul pada sampel nomor 1 hingga 6. Masing-masing zimogram isozim yang tervisualisasi dapat dilihat pada Gambar 1, 2, 3, dan 4 .

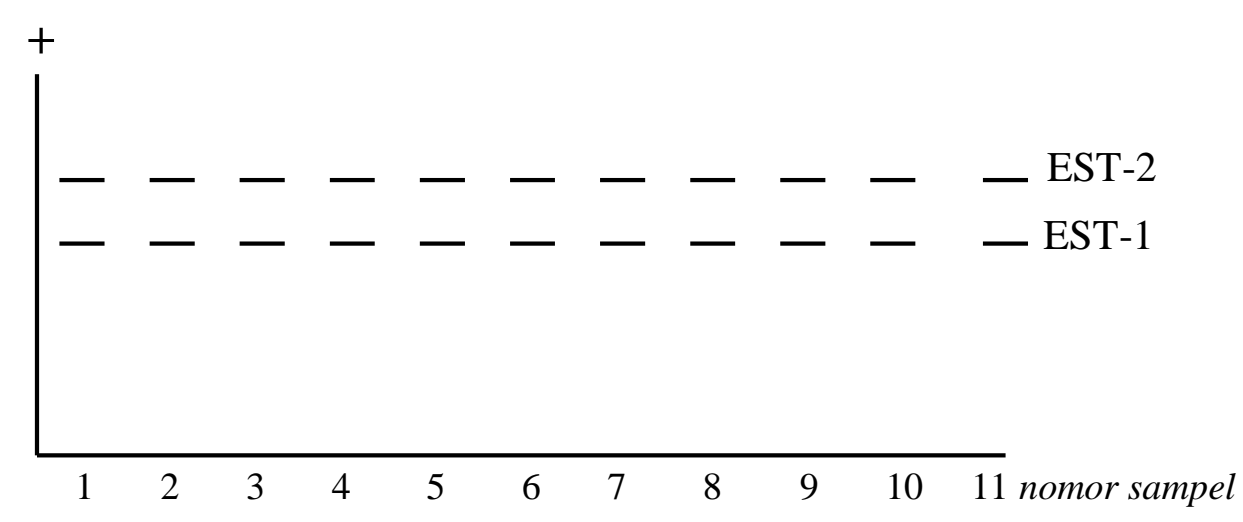

Gambar 1. Zimogram isozim esterase pada ikan betutu di Waduk Penjalin 
Pada zimogram EST nampak bahwa isozim ini diatur oleh dua lokus, yakni EST-1 dan EST-2, yang masing-masing homozigot. Hal ini berbeda dengan EST pada featherback fish (familia Noptopteridae) yang diatur oleh satu lokus dan mempunyai struktur monomer (Sodsuk dan Sodsuk, 2000). Begitu pula, pada ikan kerapu bebek (Cromileptes altivelis) EST diatur oleh satu lokus (Permana et al., 2001).

Isozim PER pada ikan betutu ternyata tidak diekspresikan oleh semua individu. Empat individu yang mengekspresikannya hanya memperlihatkan satu pola pita yang terdiri atas sebuah pita dengan arah dan jarak migrasi yang sama. Pola pita yang muncul ini mengindikasikan bahwa PER pada ikan betutu diatur oleh sebuah lokus homozigot. Hal ini berbeda dengan beberapa penelitian yang telah dilaporkan sebelumnya. Bader (1998) mengatakan bahwa kontrol genetik isozim PER terdistribusi secara multilokus dengan struktur subunit monomer atau dimer. Prentice (1984) melaporkan bahwa pada Silene diclinis isozim PER diatur oleh dua lokus, masing-masing dengan struktur subunit monomer.

Semua individu sampel yang diuji nampak mengekspresikan isozim MDH berupa satu pola pita yang terdiri atas tiga buah pit dengan arah dan jarak migrasi yang sam (Gambar 3). Beberapa hasil penelitian lainny menunjukkan bahwa MDH memiliki jumlal lokus yang bervariasi tetapi struktur subunitny selalu dimer, misalnya pada Eucinostomu gula, Eugerres plumieri, dan Diapterus auratu terdapat satu lokus (Caruz dan Alcocer, 2003) pada featherback fish terdapat dua loku (Sodsuk dan Sodsuk, 2000), pada Aphaniu fasciatus terdapat empat lokus (Maltagliat 1998), dan pada ikan kerapu bebe (Cromileptes altivelis) terdapat tiga loku (Permana et al., 2001).

Sementara itu, isozim AAT sepert terlihat pada Gambar 4 juga hany memperlihatkan satu pola pita yang sama pad individu nomor 1 hingga 6. Pada beberap penelitian sebelumnya dilaporkan bahw isozim AAT memiliki struktur dimer denga jumlah lokus yang bervariasi. Featherback fis diketahui mempunyai empat lokus AA (Sodsuk dan Sodsuk, 2000), sedangkan ika Euchinostomus gula, Eugerres plumieri, da Diapterus auratus diketahui mempunyai sat lokus isozim AAT (Caruz and Alcocer, 2003).

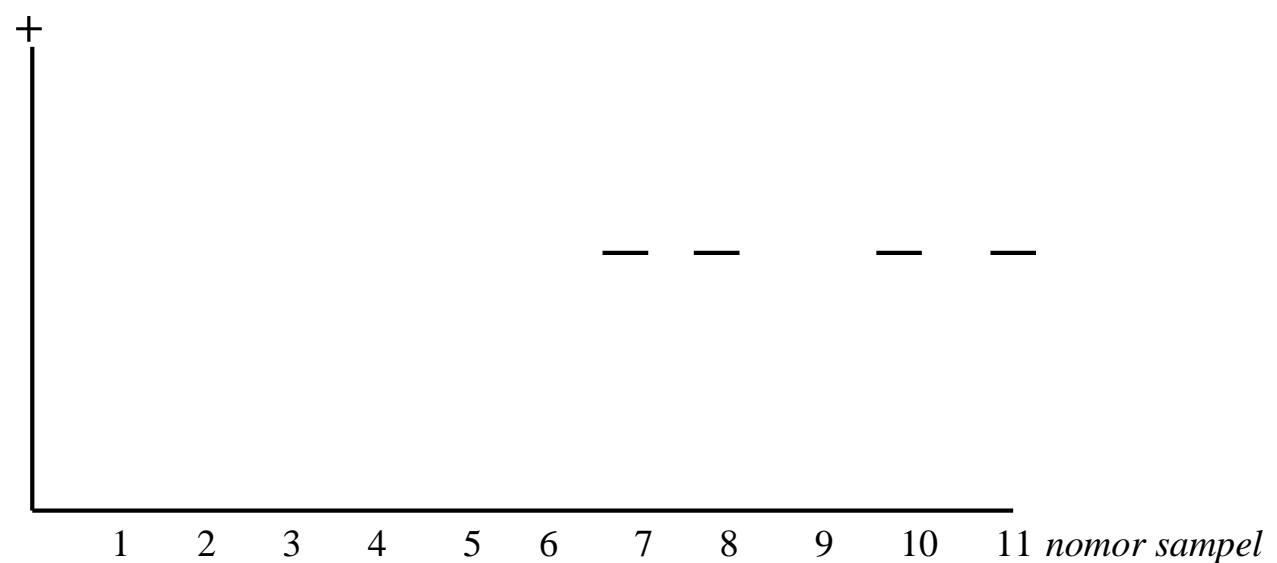

Gambar 2. Zimogram isozim peroksidase pada ikan betutu di Waduk Penjalin

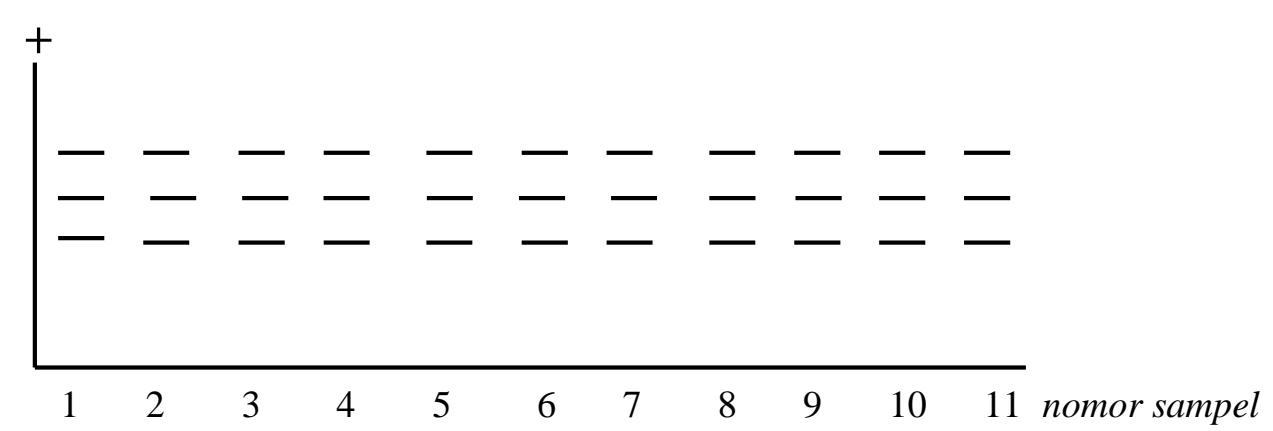

Gambar 3. Zimogram isozim malat dehidrogenase pada ikan betutu di Waduk Penjalin 
Semua lokus isozim yang tervisualisasi dapat dikatakan bersifat monomorfik karena frekuensi alelnya 1 dan 0 dengan heterozigositas sama dengan 0 . Hal ini berarti bahwa tidak terdapat variasi genetik pada populasi ikan betutu di Waduk Penjalin apabila dilihat dari isozim EST, PER, MDH, dan AAT. Hal ini diduga berkaitan dengan menurunnya ukuran populasi dan adanya isolasi geografi yang menghalangi berlangsungnya aliran gen (gene flow) dari sumber genetik lain. Menurut Smedbol et al., (2002) suatu populasi dapat terbagi menjadi beberapa subpopulasi oleh adanya isolasi reproduksi. Namun, hal ini hanya dijumpai pada spesies yang sangat terlokalisasi dengan peluang penyebaran larva yang terbatas. Kenchington dan Heino (2003) menyebutkan tiga faktor yang dapat menjadi ancaman bagi keanekaragaman hayati pada tingkat gen, yaitu (1) kepunahan atau musnahnya gen secara total, (2) hibridisasi yang mengakibatkan hilangnya kemampuan beradaptasi terhadap kondisi lokal, dan (3) menurunnya variasi genetik di dalam populasi. Faktor yang ketiga ini dapat disebabkan oleh penurunan ukuran populasi yang berpotensi meningkatkan peluang terjadinya silang dalam (inbreeding), yang akan meningkatkan homozigositas atau menurunkan heterozigositas. Selain itu, penurunan variasi genetik dapat juga disebabkan oleh pemancingan selektif (selective fishing) yang dapat berpengaruh terhadap dinamika populasi ikan.
Variasi genetik yang sangat rendah pada populasi ikan betutu di Waduk Penjalin dapat juga disebabkan oleh sifat-sifat yang berkaitan dengan fitness seperti pertumbuhan, daya hidup (viabilitas), dan kesuburan (fertilitas). Korelasi positif yang sangat signifikan antara variasi genetik dan sifat-sifat yang berkaitan dengan fitness dilaporkan oleh Knaepkens et al., (2002) pada ikan bullhead (Cottus gobio L.) di Belgia, tetapi pada ikan bullhead di Jerman tidak terlihat adanya korelasi tersebut.

Dalam beberapa generasi, rendahnya variasi genetik populasi ikan betutu di Waduk Penjalin sangat mungkin menyebabkan terjadinya tekanan silang dalam (inbreeding depression). Hal ini seperti dinyatakan oleh Larson et al., (2002) bahwa penurunan variasi genetik pada Enhydra lutris dapat mengarah kepada terjadinya tekanan silang dalam sehingga pemantauan yang ketat diperlukan untuk mencegah timbulya berbagai dampak negatif.

\section{Kesimpulan dan Saran}

Berdasarkan hasil dan pembahasan di atas dapat ditarik kesimpulan bahwa dilihat dari isozim esterase, peroksidase, malat dehidrogenase, dan aspartat aminotransferase tidak terdapat variasi genetik pada populasi ikan betutu di Waduk Penjalin Brebes. Adapun saran yang dapat diajukan adalah perlunya pembatasan yang ketat terhadap segala aktivitas yang berdampak pada penurunan ukuran populasi ikan betutu di Waduk Penjalin.

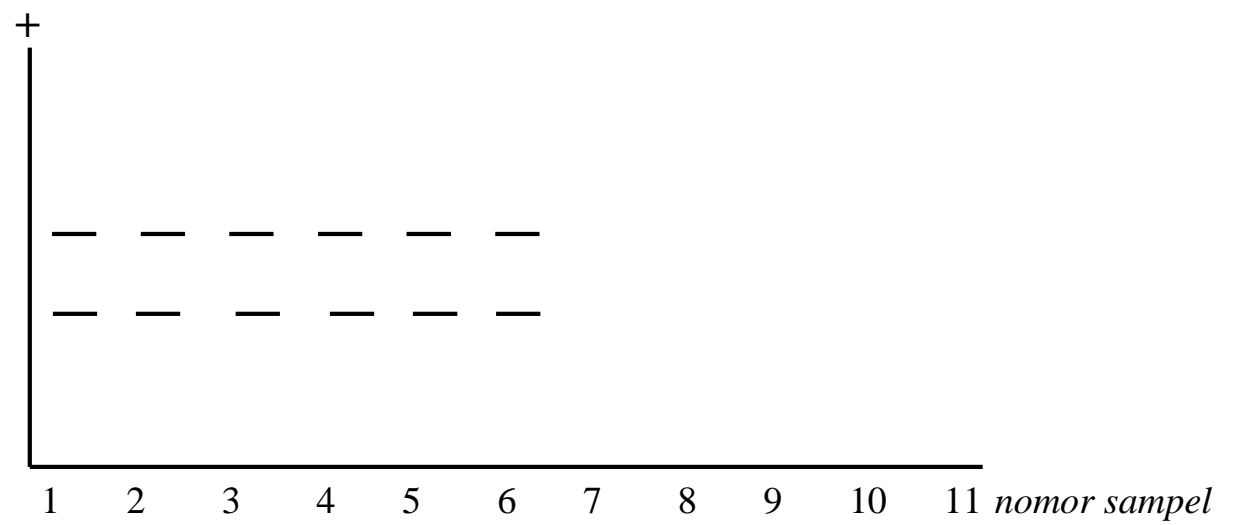

Gambar 4. Zimogram isozim aspartat amino transferase pada ikan betutu di Waduk Penjalin 


\section{Ucapan Terima Kasih}

Disampaikan ucapan terima kasih yang sebesar-besarnya kepada Proyek Anggaran Rutin Universitas Jenderal Soedirman Tahun 2004 atas dukungan dana yang diberikan.

\section{Daftar Pustaka}

Annonim. 1989. Buku Pedoman Dinas Pekerjaan Umum Perairan Pemali Hulu Ranting Bumiayu, Kabupaten Brebes. DPU Dati II Brebes.

Bader, J.M. 1998. Measuring Genetic Variability in Natural Populations by Allozyme Electrophoresis. Department of Biology, Case Western Reverse, University of Cleveland, Ohio.

Caruz, R.R. and Alcocer, M.U. 2003. Phylogenetic Assessment of Eucinostomus gula, Eugerres plumieri and Diapterus auratus (Pisces : Gerreidae) based on Allozyme and mtDNA Analysis. Caribbean Journal of Science 39 (1) : $109-115$.

Gaffar, A.K. dan Nasution, Z. 1990. Upaya Domestikasi Ikan Perairan Umum Indonesia. Jurnal Litbang Pertanian, Bogor : 8 - 12.

Hadiati, S., Murdaningsih, Baihaki, A. dan Rostini, N. 2002. Variasi Pola Pita dan Hubungan Kekerabatan Nanas Berdasarkan Analisis Isozim. Zuriat. 13 (2) : $65-72$.

Indriani, F.C., Soetopo, L., Sudjindro dan Sugiharto, A.N. 2002. Keragaman Genetik Plasma Nutfah Kenaf (Hibiscus cannabicus L.) dan Beberapa Spesies yang Sekerabat Berdasarkan Analisis Isozim. Biosains. 2 (1): $29-39$.

Kenchington, E. and Heino, M. 2003. Maintenance of Genetic Diversity: Challenges for Management of Marine Resources. Interim Report. International Institute for Applied Systems Analysis, Luxenburg.

Knaepkens, G., Knapen, D., Bervoets, L., Hanfling, B., Verheyen, E. and Eens, M. 2002. Genetic Diversity and Condition Factor : a Significant Relationship in Flemish but not in German Populations of the European Bullhead (Cottus gobio L.). Heredity 89 : 280 - 287.

Larson, S., Jameson, R., Etnier, M., Flemings, M. and Bentzen, P. 2002. Loss of Genetic Diversity in Sea Otters (Enhydra lutris) Associated with the Fur Trade of the $18^{\text {th }}$ and $19^{\text {th }}$ Centuries. Molecular Ecology 11: 1899 1903.
Maltagliati, F. 1998. A Preliminary Investigation Allozyme Genetic Variation and Populatio Geographical Structure in Aphanius fasciatu from Italian Brackish-water Habitats. Journo of Fish Biology 52 : 1130 - 1140.

Mansyah, E., Anwarudinsyah, M.J., Sadwiyanti, L. da Susiloadi, A. 1999. Variabilitas Geneti Tanaman Manggis melalui Analisis Isozir dan Kaitannya dengan Variabilitas Fenotipil Zuriat 10 (1) : 1 - 10 .

Nyuwan, S.B. 2000. Ikan Betutu Masih Menangkap da Alam. Trubus. Juli, 2000.

Permana, I.G.N., Moria, S.B., Haryati dan Sugama, K 2001. Pengaruh Domestikasi terhada Variasi Genetik pada Ikan Kerapu Bebe (Cromileptes altivelis) yang Didetek: dengan Allozyme Electrophoresis. Jurno Penelitian Perikanan Indonesia 7 (1) : 25 29.

Prentice, H.C. 1984. Enzyme Polymorphism Morphometric Variation, and Populatio Structure in a Restricted Endemic Silen diclinis (Caryophillaceae). Biologicd Journal of the Linnean Society $22: 125$ 143.

Smedbol, R.K., McPherson, A.A., Hansen, M.M. an Kenchington, E. 2002. Myths an Moderation in Marine 'Metapopulations' Fish and Fisheries $3: 20-35$.

Sodsuk, P.K. and Sodsuk, S. 2000. Genetic Diversity o Featherback Fish in Thailand. Kasetsa Journal (Nat. Sci.) 34 (2) : 227 - 239.

Suryadi, H. 2002. Draft Dokumen IBSAP Bagian $3 / 8$ Tinjauan : Keanekaragaman Hayati sebaga Aset Produktif Pembangunan Berkelanjutar www.polarhome.com (Email: nasiona a@polarhome). 2 Mei 2002.

Suryani, S.A.M.P., Sukoso dan Sugama, K. 2001] Hubungan Kekerabatan Tiga Spesies Ika Kerapu Sunu (Plectropomus spp.) atas dasa Variasi Genetik. Biosains 1 (3) : $100-108$.

Susanto, A.H., Amurwanto, A. dan Nuryanto, A. 2004: Studi Keanekaragaman Genetik Ika Anguilla di Kawasan Segara Anakan untu Menunjang Upaya Konservasi Hayat Biosfera 21 (1) : $9-16$.

Susanto, A.H., Amurwanto, A. dan Nuryanto, A. 2004t Studi Keanekaragaman Genetik Ika Bandeng (Chanos chanos Forskal) Tambak Pantai Cilacap dan Tegal untu Menunjang upaya Konservasi Hayati. Sain Akuatik 7 (1) : 9 - 15 